\title{
Pengaruh fee audit, rotasi auditor, reputasi KAP, audit delay terhadap kualitas audit
}

\author{
Sonya Marantika Sitompul*; Melisa Panjaitan; Wenny Anggeresia Ginting
}

\author{
Prodi Akuntansi, Fakultas Ekonomi, Universitas Prima Indonesia, Medan \\ *E-mail korespondensi: sonyasitompul02@gmail.com
}

\begin{abstract}
The purpose of this study was to determine the effect of audit fees, auditor rotation, $K A P$ reputation, and audit delay on audit quality. The unit of analysis is property, real estate, and construction companies listed on the Indonesia Stock Exchange in 20172019. The data used by the researcher was obtained from financial report data. The population is property, real estate, and construction companies on the IDX. In taking the sample using purposive sampling technique, and obtained a number of 22 companies multiplied by three years of the research period. The data analysis used is descriptive using SPSS version 23. The results show that simultaneously audit fees, auditor rotation, KAP reputation, and audit delay do not affect audit quality. For further research, it is hoped that researchers will add years of observation.
\end{abstract}

Keywords: Auditor rotation, KAP reputation, Audit delay, Audit quality.

Abstrak

Tujuannya penelitian ini ialah untuk mengetahui pengaruh fee audit, rotasi auditor, reputasi KAP dan audit delay terhadap kualitas audit. Unit analisis adalah perusahaan property, real estate dan kontruksi yang terdaftar dalam BEI tahun 2017- 2019. Data yang dipergunakan peneliti didapatkana dari data laporan keuangan. Adapun populasinya ialah perusahaan property, real estate dan kontruksi pada BEI. Dalam pengambilan sampelnya menerapkan teknik purposive sampling dan didapatkan sejumlah 22 perusahaan dikalikan 3 tahun periode penelitiannya. Analisis data yang digunakan ialah deskriptif berbantuan SPSS versi 23. Adapun hasilnya memperlihatkan secara serentak fee audit, rotasi auditor, reputasi KAP dan audit delay tidak mempengaruhi kualitas audit. Bagi penelitian selanjutnya diharapkan untuk peneliti menambah tahun pengamatannya.

Kata kunci: Rotasi audit, Reputasi KAP, Audit delay, Kualitas audit.

\section{PENDAHULUAN}

Kompetisi di masa globalisasi di bidang bisnis berkembang dengan sangat pesat, seperti kompetisi pada layanan jasa akuntan publik. Seiring berkembangnya perusahaan go public di negara ini yang sangat maju, hal tersebut berakibat pada permintaan audit laporan keuangan yang mengalami peningkatan. Audit laporan keuangan sangat dibutuhkan perusahaan. Laporan keuangan yang sudah melewati audit oleh akuntan publik cenderung terpercaya kewajarannya daripada yang tidak atau sama sekali belum dilakukan audit. Sesuai SPAP, audit yang auditor laksanakan dinyatakan berkualitas apabila sesuai dengan regulasi yang ditentukan. Standar auditing ialah pedoman untuk auditor dalam melaksanakan audit dari laporan keuangan historis yang meliputi 10 standar dan diperinci berbentuk PSA. 
Berdasar PSAK No.1 tahun 2017, karakteristik kualitatif dalam pembuatan laporan keuangan yakni bisa dimengerti, relevan, bisa diandalkan dan diperbandingkan. Hasil dari laporan tersebut sangat menunjang pengguna laporan dalam menentukan suatu keputusan.

Peneliti sebelumnya dari Pramaswaradana \& Astika (2017), menunjukan fee audit berpengaruh positif terhadap kualitas audit sedangkan umur publikasi, rotasi auditor, dan spesialisasi auditor tidak berpengaruh terhadap kualitas audit. Adapun Wiranti (2018), menunjukan Rotasi Audit berpengaruh positif terhadap Kualitas Audit, Spesialisasi Auditot dan Ukuran KAP tidak berpengaruh terhadap Kualitas Audit. Peneliti Evi Herianti (2016) menunjukan bahwa audit delay tidak berpengaruh terhadap Kualitas Audit.

Faktor pertama Menurut Permatasari \& Astuti (2019) menyatakan bahwa Fee Audit ialah biaya yang diperoleh auditor dari perusahaan klien yang diaudit. Penentuan besarnya Fee audit berdasar pada perjanjian diantara auditor dengan auditee disesuaikan dengan waktu pelaksanaan pengauditannya dan banyaknya staff yang diperlukan untuk proses auditnya.

Faktor yang kedua yaitu Rotasi Auditor, pendapat Lasniar (2018) mengungkapkan Rotasi Audit merupakan pergantian auditor baik kantor akuntan publik maupun akuntan publiknya.

Faktor yang ketiga yang mempengaruhi kualitas audit yaitu Reputasi KAP, tolak ukur kualitas audit dapat dilihat dari Reputasi KAP. KAP yang reputasinya tinggi atau namanya baik maka cenderung lebih memperhatikan nama baiknya melalui penampilan kualitas audit yang baik.

Selanjutnya adalah audit delay ialah lama atau jarak waktu untuk menyelesaikan audit diawali dari tanggal tutup tahun buku hingga tanggal dikeluarkannya laporan audit yang mengakibatkan adanya inefisiensi pasar dan menurunkan relevansi informasi keuangan laporan keuangan yang berdampak menurunnnya kualitas audit.

Pendapat Ardani (2017) kualitas audit ialag segala kemungkinan dimana auditor pada saat mengaudit laporan keuangan klien dapat menemukan pelanggaran yang terjadi dalam sistem akuntansi klien dan melaporkannya dalam laporan keuangan auditan, dimana dalam melaksanakan tugasnya tersebut auditor berpedoman pada standar auditing dan kode etik akuntan publik yang relevan. Dalam menjalankan tugas selaku auditor membutuhkan kepercayaan kepada mutu jasa yang diberikan ke stakeholder. Sangatlah berarti pandangan stakeholder atas Kantor Akuntan Publik (KAP) selaku pihak yang independen dan ahli, dikarenakan bisa berpengaruh pada berharga atau tidak jasa dari KAP ke stakeholder. Bila pengguna menganggap hasil dari KAP berharga atau bermanfaat maka kualitas auditnya juga baik. Sehingga KAP diharuskan dalam melaksanakan tugasnya untuk bersikap profesionalisme.

Berkaitan dengan kualitas audit, banyak ditemukan kasus hukum yang terdapat manipulasi akuntansi atau pada laporan keuangannya. Berikut ini Skandal manipulasi akuntansi atau manipulasi laporan keuangan yang melibatkan beberapa perusahaan Property, Real estate dan Kontruksi.

Fenomena yang terjadi yaitu PT. Bakrieland Developmet Tbk tidak menampilkan kewajiban berjangka panjang yang sesungguhnya pada laporan keuangan. PT ini mempunyai utang oblgasi ke Bank of New York Mellon dan tidak bisa menyelesaikan pembayarannya ketika jatuh tempo. Sehingga PT tersebut megajukan Penundaan Kewajiban Pembayaran Utang (PKPU) untuk merencanakan perdamaian dengan Bank of New York Mellon berkaitan dengan 
kewajibannya dalam melunasi utangnya (www.detikfinance.com). Namun PT. Bakrieland Developmet Tbk tidak menampilkan permasalahan ini pada laporan keuangan yang seharusnya masalah tersebut harus dilaporkan sebagai perusahaan yang terbuka. Pendapat Nurhaida sebagai Kepala Eksekutif Pengawas Pasar Modal mengungkapkan yakni bagi perusahaan terbuka mesti melaporkan tiap masalah yang mempengaruhi publik (www.bisins.liputan6.com).

Dari fenomena tersebut dapat disimpulkan bahwa banyak kasus manipulasi laporan keuangan, dengan pandangan "wajar tanpa pengecualian" namun opini tersebut tidak selaras dengan realita setelah diperiksa kembali oleh OJK. Dari kasus diatas dapat dilihat bahwa kegagalan audit laporan keuangan oleh KAP dikarenakan akuntan publik dan tim auditor bersangkutan tidak menerapkan standar audit agar relevan dengan kode etik yang ditetntukan. Akibat dari kegagalan audit atas laporan keuangan dapat menimbulkan rapuhnya kredibilitas dan kepercayaan terhadap KAP dan dapat menurunkan kualitas audit.

Berdasar latar belakang yang diungkapkan diatas maka penulis berkeinginan meneliti lebih dalam mengenai faktor yang mempengaruhi kualitas audit sehingga mengangkat penelitian baru yang judulnya "Pengaruh fee audit, rotasi auditor, reputasi kap dan audit delay terhadap kualitas audit".

\section{TINJAUAN PUSTAKA}

Penelitian (Agustini \& Siregar,2020) yang berjudul Pengaruh Fee audit, audit tenure dan rotasi audit terhadap kualitas audit di Bursa Efek Indonesia menunjukan bahwa Fee Audit dan Rotasi Audit tidak berpengaruh secara signifikan terhadap Kualitas Audit. Penelitian (Permatasari \& Astuti,2018) memberika pendapat sebaliknya dengan judul penelitian Pengaruh Fee Audit, Rotasi Audit, dan Reputasi KAP terhadap kualitas Audit menunjukan bahwa Fee Audit berpengarus secara signifikan terhadap Kualitas Audit.

\section{Pengaruh fee audit terhadap kualitas audit}

Fee audit ialah biaya yang didapatkan auditor atas pertimbangan sejumlah risiko misalnya kompleksitas jasa yang dilakukan, taraf kompetensi dan lainnya. Pendapat Latifhah, Oktaroza \& Sukarmanto, (2019) dimana dengan Fee audit yang besar auditor cenderung akan melaksanakan audit dengan mekanisme audit yang optimal. Dalam laporan keuangan Fee Audit dapat dilihat dari Profesional Fees yang terdapat pada laporan keuangan (Ninik \& Nursiam,2018).

\section{Pengaruh rotasi audit terhadap kualitas audit}

Rotasi audit merupakan pergantian akuntan publik dimana akuntan publik di Indonesia hanya dapat mengaudit laporan keuangan perusahaan maksimal 3 tahun berturut-turut (Andriani \& Nursiam,2017). Berdasarkan keterangan bersangkutan timbul anggapan yakni makin lama hubungan diantara auditor dengan klien bisa menurunkan independensi auditornya. Pada penelitan ini Rotasi audit dapat dilihat berdasar variabel dummy, 1 apabila terjadi rotasi dan 0 bila tidak terjadi rotasi ( Ninik \& Nursiam,2018).

\section{Pengaruh reputasi KAP terhadap kualitas audit}

Reputasi KAP sangat berkaitan dengan ukuran KAP disebabkan adanya ketaksamaan kualitas auditor dan independensi diantara perusahaan audit Big 4 dengan non Big 4. Menurut Sulastono (2016), kualitas auditor yang ada dalam kantor akuntan yang punya reputasi big four, yang dianggap memiliki kecepatan, ketepatan dan memiliki sarana serta prasarana yang lebih baik dari auditor kantor 
akuntan non big four. Indikator dari Reputasi KAP yaitu dummy, 1 pada KAP Big 4 dan 0 pada KAP non Big 4.

\section{Pengaruh audit delay terhadap kualitas audit}

Audit delay diartitikan perbedaan waktu antara tanggal laporan keuangan dengan tanggal opini audit dalam laporan keuangan menunjukkan tentang lamanya waktu penyelesaian audit (Fauziyah,2016). Audit delay berhubungan dengan tepat dan tidaknya waktu pengungkapan laporan keuangan sehingga kualitas laporan yang dipublikasikan dapat dipengaruhi audit delay.

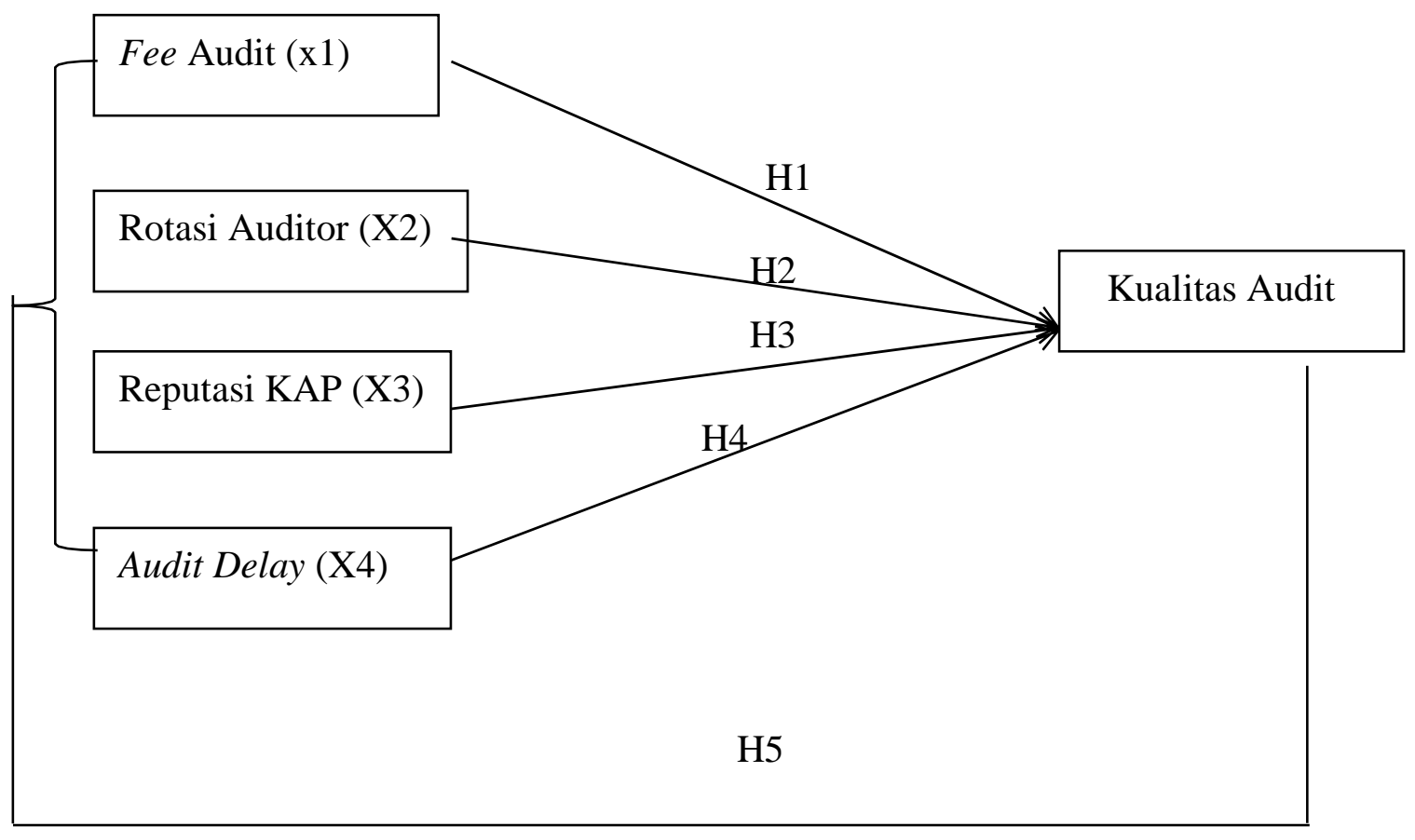

Gambar 1. Kerangka konseptual

\section{Hipotesis penelitian}

H1: Fee audit berpengaruh pada kualitas audit pada perusahaan property, real estate, dan kontruksi yang listing di BEI periode 2017-2019

$\mathrm{H} 2$ : Rotasi audit berpengaruh pada kualitas audit pada perusahaan property, real estate, dan kontruksi yang listing di BEI periode2017-2019

H3: Reputasi KAP berpengaruh pada kualitas audit pada perusahaan property, real estate, dan kontruksi yang listing di BEI periode2017-2019

H4: Audit delay berpengaruh pada kualitas audit pada perusahaan property, real estate, dan kontruksi yang listing di BEI periode2017-2019

H5 : Fee audit, rotasi auditor, reputasi KAP, audit delay berpengaruh terhadap kualitas audit pada perusahaan property, real estate, dan kontruksi yang listing di BEI periode 2017-2019.

\section{METODE}

Peneliti mengambil tempat penelitian melalui BEI. Hasil data perusahaan Property, real estate dan konstruksi diambil dalam waktu 3 tahun dari 2017-2019. Semua data dan laporan keuangan diperoleh dari situs BEI melalui www.idx.co.id .

Penelitian ini berjenis Penelitian kausal karena merupakan penelitian yang sifatnya sebab akibat. Adapun sifat penelitiannya ialah deskriptif. Peneliti menggunakan pendekatan penelitian kuantitatif. 


\section{Populasi dan sampel}

Populasi yang diteliti ialah seluruh perusahaan property, real estate dan kontruksi yang lisitng di BEI tahun 2017-2019 sejumlah 59 perusahaan. Peneliti menerapkan teknik sampling yang berupa purposive sampling, dimana pemilihan sampel dilakukan dengan menggunakan pemilahan berdasarkan kualifikasi tertentu.

Tabel 2. Kriteria pemilihan sampel

\begin{tabular}{llc}
\hline No & \multicolumn{1}{c}{ Kriteria } & Jumlah \\
\hline 1 & $\begin{array}{l}\text { Perusahaan Property, Real Estate dan Konstruksi yang listing di BEI } \\
\text { tahun 2017-2019 }\end{array}$ & 59 \\
\hline 2 & $\begin{array}{l}\text { Perusahaan Property, Real Estate dan Konstruksi yang tidak } \\
\text { mengupload }\end{array}$ & $(19)$ \\
& $\begin{array}{l}\text { Laporan Tahunan secara berurutan mulai dari 2017-2019 } \\
\text { Perusahaan Property, Real estate dan Konstruksi yang tidak } \\
\text { mengalami } \\
\text { keuntungan secara berurutan mulai 2017-2019 }\end{array}$ & $(18)$ \\
\hline Jumlah perusahaan yang menjadi sampel & 22 \\
\hline Jumlah sampel penelitian (3x22) & 66
\end{tabular}

Sumber: www.idx.co.id(diolah)

Adapun keseluruhan sampelnya ialah 66 sampel yang diperoleh dari banyaknya sampel 22 perusahaan dikali dengan 3 tahun periode penelitiannya.

\section{Identifikasi variable penelitian}

Variable dependent yang digunakan ialah kualitas audit (Y). variable independent yang diteliti ialah fee audit (X1), rotasi auditor (X2), reputasi KAP (X3), audit delay (X4).

\section{Teknik analisis data}

\section{Uji multikolinieritas}

Uji tujuannya untuk mengetahui apakah model regersinya berkorelasi diantara variabel independennya. Regresi yang baik ialah yang tidak berkorelasi diantara variabel independennya, namun bila variabel bebasnya terjadi korelasi satu sama lain maka variabel ini tidak orthogonal.

\section{Analisi regresi logistik}

Dalam menguji hipotesisnya memakai model analisis multivariate melalui regresi logistic dikarenakan variabel bebasnya berupa perpaduan dari variabel kontinyu dengan kategorikal. Persamaan regresi logistiknya bisa dituliskan di bawah ini:

\section{$\mathbf{Y}=\alpha+\beta_{1} \mathbf{F A}+\boldsymbol{\beta}_{2} \mathbf{R A}+\boldsymbol{\beta}_{3} \mathbf{R E K A P}+\boldsymbol{\beta}_{4} \mathrm{AD}+\mathrm{e}$}

Keterangan :

Y : Kualitas audit

A : Konstanta

B : Koefisien regresi

FA $\quad$ :Fee audit

RA : Rotasi auditor

REKAP : Reputasi audit

AD : Audit delay

E : Error 


\section{Overall model fit}

Dipergunakan untuk mengetahui model yang sudah dihipotesis sudah fit dengan data ataukah tidak. Hipotesis dalam menilai model fit ialah: $\mathrm{H}_{0}=$ model yang dibuat hipotesis sudah fit dengan datanya dan $\mathrm{Ha}=$ model yang hipotesisnya tidak fit dengan datanya. Untuk menguji hipotesinya, L ditransformasi ke dalam -2LogL. Model regresi yang baik ditunjukkan dengan penurunan Likelihood (-2LL) atau model yang dihipotesiskan fit dengan datanya.

\section{Uji kelayakan model regresi logistik}

Bisa diketahui melalui Hosmer and Lemeshow's Goodness of fit test. Model ini mengujikan $\mathrm{H}_{0}$ model tersebut melakukan pengujian terhadap $\mathrm{H}_{0}$ untuk melihat kecocokan data dengan model. Untuk menilai Hosmer and Lemeshow's Goodness of fit test, Jika nilainya $\leq 0.05$, maka menolak $\mathrm{H}_{0}$ dan bila nilainya $>0,05$ maka menerima $\mathrm{H}_{0}$.

\section{Koefisien determinasi}

Pendapat Ghozali (2011) koefisien determinasi $\left(\mathrm{R}^{2}\right)$ bertujuan melihat sejauh mana kemampuan modelnya dalam menjelsakan varian variabel dependen. Adapun nilai $\mathrm{R}^{2}$ berkisar 0 hingga 1 . Bila nilainya hampir 0 , maka kemampuan variabel bebas dalam menerangkan variabel terikatnya sangatlah terbatas. Kebalikannya, bila nilainya hampir 1, maka variabel bebas memberi seluruh informasi yang diperlukan untuk memperkirakan variabel terikat

\section{HASIL DAN PEMBAHASAN}

\section{Statistik deskriptif}

Berdasarkan Tabel 4. Memperlihatkan analisis statistik deskriptif variabel yang dipakai pada penelitian ini meliputi jumlah observasi, mean serta serta standar deviasi.

Tabel 4. Statistik deskriptif

\begin{tabular}{ccccrr}
\hline Variabel & N & Minimum & Maximum & Mean & Std. deviation \\
\hline X1 & 66 & 15 & 78 & 26.35 & 10.135 \\
X2 & 66 & 0 & 1 & .47 & .503 \\
X3 & 66 & 0 & 1 & .36 & .485 \\
X4 & 66 & 24 & 95 & 72.12 & 20.689 \\
Y & 66 & 0 & 1 & .50 & .504 \\
Valid N (listwise) & 66 & & & & \\
\hline
\end{tabular}

Sumber: Data diolah, 2021

Perhitungan tersebut terlihat bahwa dari 22 perusahaan property, real estate dan konstruksi dengan sampel 3 tahun pengamatan $(22 \times 3)$ maka $\mathrm{N}=66$. 1).Adapun hasil analisis terhadap Fee Audit menunjukan nilai minimumnya 15 , nilai maksimumnya 78 , nilai rerata 26,35 dan standar deviasi 10,135. 2).Hasil analisis terhadap Rotasi Auditor menunjukan nilai nilai minimumnya 0 , nilai maksimumnya 1 , nilai rerata 0,47 dan standar deviasi 0,503. 3).Hasil analisis terhadap reputasi KAP menunjukan nilai nilai minimumnya 0 , nilai maksimumnya 1 , nilai rerata 0,36 dan standar deviasi 0,485.4).Hasil analisis terhadap audit delay menunjukan nilai nilai minimumnya 24 , nilai maksimumnya 95, nilai rerata 72,12 dan standar deviasi 20,689. 5).Hasil analisis terhadap kualitas audit menunjukan nilai nilai minimumnya 0 , nilai maksimumnya 1 , nilai rerata 0,50 dan standar deviasi 0,504 . 


\section{Model fit (overall fit model test)}

Hasil dari pengujiannya ini dilihat dengan melakukan perbandingan antara nilai 2 log likelihood (-2LL) di awal (block number $=0$ ) yang bernilai -2 log likelihood (2LL) di akhir (block number $=1$ ).

Tabel 4. Overall fit model test

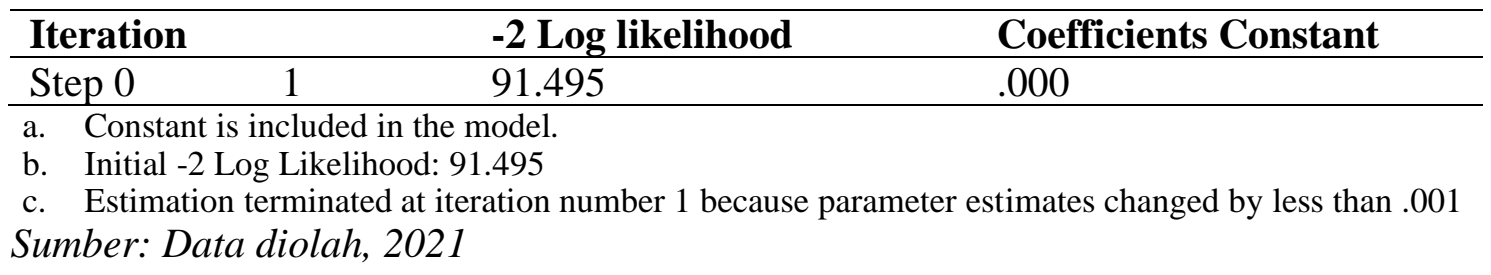

Nilai -2LL awal ialah 91,495, sesudah seluruh datanya dimasukkan untuk empat variabel bebas, maka nilai -2LL adalah 84.479. Terdapat penurunan likelihood (-2LL) hal tersebut mengindikasikan jika model regresinya lebih baik ataupun sudah model fit.

Tabel 5. Overall fit model test

\begin{tabular}{rrrrrrrr}
\hline \multirow{2}{*}{ Iteration } & \multirow{2}{*}{$\begin{array}{c}\text {-2 Log } \\
\text { likelihood }\end{array}$} & \multicolumn{6}{c}{ Coefficients } \\
\cline { 3 - 8 } Step 1 & 1 & 84.952 & -.905 & .060 & .153 & -.323 & -.009 \\
& 2 & 84.496 & -1.425 & .081 & .177 & -.343 & -.009 \\
& & 84.479 & -1.547 & .087 & .179 & -.348 & -.009 \\
& 4 & 84.479 & -1.552 & .087 & .179 & -.348 & -.009 \\
& 5 & 84.479 & -1.552 & .087 & .179 & -.348 & -.009 \\
\hline
\end{tabular}

a. Method: Enter

b. Constant is included in the model.

c. Initial -2 Log Likelihood: 91.495

d. Estimation terminated at iteration number 5 because parameter estimates changed by less than .001 .

Sumber: Data diolah, 2021

\section{Koefisien determinasi (Nagelkerke $\mathbf{R}$ square)}

Digunakan untuk melihat akurasi analisa regresi dan untuk menlihat persentase perubahan variabel dependen yang dipengaruhi dari variabel independen.

Tabel 6. Koefisien determinasi

\begin{tabular}{|c|c|c|c|}
\hline Step & -2 Log likelihood & $\begin{array}{c}\text { Cox \& Snell R } \\
\text { Square }\end{array}$ & $\begin{array}{c}\text { Nagelkerke R } \\
\text { Square }\end{array}$ \\
\hline 1 & $84.479^{a}$ & .101 & .134 \\
\hline
\end{tabular}

a. Estimation terminated at iteration number 5 because parameter estimates changed by less than .001 .

Sumber: Data diolah, 2021

Pada Tabel 6 tersebut dapat dicermati jika nilai dalam kolom Negalkerte $R$ Square adalah 0.093 yang artinya jika variabel terikat yang bisa diterangkan dari variabel independen adalah $9.3 \%$ dan sisanya dijelaskan variabel dari luar model yang digunakan sebesar 90,7\%. Hal tersebut menujukan bahwa variabel-variabel diluar model penelitian seperti audit tenure, ukuran perusahaan, opini audit, dan lainnya.

\section{Uji kelayakan regresi (Hosmer and Lemeshow test)}

Analisis yang digunakan adalah Hosmer and Lemeshow test yang diukur dengan Chi-Square. Apabila hasil pengujiannya menunjukkan tingkat siginifikansi yang $<0.05$, maka menolak $\mathrm{H}_{0}$ dan modelnya dinyatakan tidak fit, kebalikannya apabila tidak signifikan maka tidak bisa menolak $\mathrm{H}_{0}$ yang artinya data empirisnya sama dengan model ataupun modelnya dinyatakan fit (Ghozali 2016:329). 
Tabel 7. Uji kelayakan regresi Hosmer and Lemeshow test

\begin{tabular}{cccc}
\hline Step & Chi-square & Df & Sig. \\
\hline 1 & 11.973 & 7 & .101 \\
\hline
\end{tabular}

Sumber: Data diolah, 2021

Adapun Tabel 7 memperlihatan nilai dari uji Hosmer and Lemeshow test adalah 0.101. Dikarenakan nilai signifikansinya > $0.05(5 \%)$, jadi bisa ditarik kesimpulan jika H0 diterima yang artinya jika modelnya sanggup memperkirakan nilai pengamatan ataupun bisa dinyatakan jika modelnya diterima sebab tidak ada perbedaan dengan datanya, hal ini mengindikasikan jika modelnya sanggup memperkirakan nilai observasi ataupun bisa dinyatakan modelnya bisa diterima dikarenakan cocok dengan datanya (Ghozali, 2016).

\section{Matriks klasifikasi}

Matriks klasifikasi menunjukan perkiraan dari model regresi dalam

memperkirakan kualitas audit yang dilakukan oleh perusahaan Property, Real estatedan Konstruksi. Dari tabel klasifikasi diatas diketahui hasil klasifikasi dalam penghitungan nilai prediksi yang benar dan salah.

Tabel 8. Matriks klasifikasi

\begin{tabular}{lccccc}
\hline & & \multicolumn{3}{c}{ Predicted } & \\
\cline { 3 - 4 } & \multirow{2}{*}{ Observed } & \multicolumn{2}{c}{ Percentage } \\
& & $\begin{array}{c}\text { Kualitas } \\
\text { tidak baik }\end{array}$ & $\begin{array}{c}\text { Kualitas } \\
\text { baik }\end{array}$ & \\
\cline { 3 - 4 } & & 24 & 9 & 72.7 \\
Step 1 & Y & kualitas tidak baik & 17 & 16 & 48.5 \\
\cline { 2 - 4 } & kualitas baik & & & 60.6 \\
\cline { 2 - 4 } & & Overall Percentage & & & \\
\hline
\end{tabular}

a. The cut value is .500

Sumber: Data diolah, 2021

Berdasarkan perkiraan, prusahaan yang masuk dalam kategori kualitas audit tidak baik sejumlah 33 perusahaan. Sementara perusahaan yang masuk dalam kualitas audit baik adalah sebanyak 33 perusahaan. Sehingga nilai overall percentage sebelum variabel dimasukkan kedalam model sebesar 60,6\%.

\section{Uji hipotesis}

\section{Model regresi logistik}

Disini uji hipotesis yang digunakan adalah regresi logistik, yakni menguji pengaruhnya fee audit, rotasi audit, reputasi KAP, dan audit delay terhadap kualitas audit.

Tabel 9. Model regresi logistik

\begin{tabular}{cccccccc}
\hline & & B & S.E. & Wald & df & Sig. & $\operatorname{Exp(B)}$ \\
\hline Step $1^{\text {a }}$ & FE & .087 & .043 & 4.020 & 1 & .045 & 1.091 \\
& RA & .179 & .538 & .111 & 1 & .739 & 1.196 \\
& REKAP & -.348 & .554 & .395 & 1 & .530 & .706 \\
& AD & -.009 & .013 & .478 & 1 & .489 & .991 \\
& Constant & -1.552 & 1.456 & 1.136 & 1 & .287 & .212 \\
\hline
\end{tabular}

a. Variable(s) entered on step 1: FE, RA, REKAP, AD

Sumber: Data diolah, 2021 
Berdasarkan Tabel 9 hasil pengujiannya adalah sebagai berikut :

$$
\mathrm{KA}=-\mathbf{1 , 5 5 2}+\text { 0,087FA + 0,179RA - 0,348REKAP - 0,009AD + e }
$$

Berdasarkan persamaan diatas, model memiliki nilai koefisien konstanta yakni 1,552 dengan nilai negatif tersebut bisa disimpulkan apabila jika nilai variabel bebasnya 0 , maka kualitas audit cenderung menurun sebesar $-1,552$

Berdasarkan persamaan diatas, terlihat jika nilai koefisien Fee Audit sebesar 0,087, jadi bisa dijelaskan jika Fee audit cenderung mempengaruhi dengan positif terhadap Kualitas audit.

Berdasarkan persamaan diatas, diartikan jika nilainya koefisien Rotasi audit adalah 0,0179, jadi bisa dijelaskan jika Rotasi audit cenderung mempengaruhi positif terhadap Kualitas audit.

Berdasarkan persamaan diatas, bisa disimpulkan jika nilai koefisien reputasi KAP sebesar -0,348, jadi bisa dijelaskan jika Reputasi KAP cenderung mempengaruhi secara negatif terhadap Kualitas audit.

Berdasarkan persamaan diatas, bisa dijelaskan jika nilai koefisien Audit Delay sebesar -0,009, jadi bisa dilihat jika Audit Delay cenderung mempengaruhi secara negatif terhadap Kuallitas audit.

\section{Uji simultan}

Berdasarkan tabel diatas memperlihatkan nilai df yaitu 4 dan chi 7,017 dengan nilai signifikansinya 0,135 . Nilai signifikansi yang didapat itu $>0.05(5 \%)$. Yang artinya secara serentak Fee audit, rotasi audit, reputasi KAP dan audit delay tidak mempengaruhi secara bersamasama pada kualitas audit.

Tabel 10.Uji simultan omnibus tests of model coefficients

\begin{tabular}{llccc}
\hline & & Chi-square & Df & Sig. \\
\hline Step 1 & Step & 7.017 & 4 & .135 \\
& Block & 7.017 & 4 & .135 \\
& Model & 7.017 & 4 & .135 \\
\hline
\end{tabular}

Sumber: Data diolah, 2021

\section{Fee audit terhadap kualitas audit}

Hasil pengujian hipotesis variabel $\mathrm{Fee}$ audit menunjukan koefisien 0,087 dan taraf signifikan 0,045 dan <0,05. Maka hal tersebut memperlihatkan hipotesis bisa diterima dimana Fee audit mempengaruhi secara positif terhadap kualitas audit pada perusahaan property, real estate dan konstruksi yang tercatat di BEI tahun 2017-2019. Hal ini sejalanaan dengan penelitian yang yang dilaksanakan (Pramaswaradana \& Astika, 2017) yang menyimpulkan jika Fee audit mempengaruhi secara positif pada kualitas audit. Jika Fee yang semakin besar akan menambah kinerja auditor sehingga menghasilkan pekerjaan yang semakin berkualitas. Hasil tersebut bertentangan dengan hasil penelitiannya (Novrilia et al., 2019) yang menyimpulkan jika Fee audit tidak memberikan pengaruh pada kualitas audit.

\section{Rotasi auditor terhadap kualitas audit}

Hasil uji hipotesis variabel rotasi auditor mrnunjukan nilai koefisien 0,179 dan taraf signifikan 0,793 dan >0,05. Jadi hipotesisnya tidak bisa diterima yaitu rotasi audit tidak berpengaruh terhadapbaik atau tidaknya kualitas audit pada perusahaan property, real estate dan konstruksi di BEI Tahun 2017-2019. Hal ini dikarenakan makin lama perusahaan melakukan rotasi maka hasil auditnya juga semakin baik. Hasil penelitian tersebut sejalan dengan penelitiannya Hartadi (2012) yan menyimpulkan jika rotasi 
audit tidak mempengaruhi kualitas audit. Nilai koefisien regresi yang negatif memperlihatkan ada korelasi yang bertentangan yang artinya makin sedikit perusahaan manjalankan rotasi audit, makin baik hasil auditnya. Hasil penelitian ini membuktikan jika menjalankan rotasi audit bukanlah sebuah jaminan untuk mendapatkan hasilkan audit yang baik. Pendapat dari Hartadi (2012) hal tersebut dikarenakan sebetulnya pasar tidak ambil pusing apkah auditor yang membuat pernyataan opini dalam laporan keuangan tahunan itu pernah dirotasi ataupun belum.

\section{Reputasi KAP terhadap kualitas audit}

Hasil uji hipotesis veriabel reputasi KAP menunjukan koefisien -0,348 dengan nilai signifikansinya 0,530 dan $>0,05$. Maka hal tersebut membuktikan reputai KAP tidak mempengaruhi kualitas audit dalam perusahaan property, real estate dan konstruksi di BEI Tahun 2017-2019. Hal ini dikarenakan KAP big four ataupun non big four tidak bisa memprediksi kualitas audit suatu perusahaan. Penelitian ini menunjukan tidak adanya pengaruh reputasi KAP terhadap kualitas audit. Hal tersebut dikuatkan dengan penelitiannya Hartadi (2012) yang menyiimpulkan jika reputasi auditor tidak mempengaruhi kualitas audit. Astrini (2013) menjelaskan jika investor akan semakin yakin dengan data akuntasi yang didapatan dari auditor yang mempunyai reputasi.

\section{Audit delay terhadap kualitas audit}

Hasil uji hipotesis variabel audit delay memperlihatkan koefisien -0,009 dengan nilai signifikaansinya 0.489 dan $>0,05$. Maka hal tersebut membuktikan jika tidak ada pengaruh antara audit delay terhadap kualitas audit. Hal ini disebabkan perusahaan property, real estate dan konstruksi menyampaikan laporan auditnya dalam jangka waktu yang hampir sama yaitu 80 hari. Hal tersebut dikuatkan dengan penelitiannya Eva (2016) yang menyimpulkan jika audit delay tidak mempengaruhi kualitas audit.

Hasil penelitian ini memperoleh nilai chi square 5,393 dengan taraf signifikansinya 0,612. Sehingga dengan nilai signifikansinya $>0.05(5 \%)$. Bisa dinyatakan jika Fee audit, rotasi audit, reputasi KAP dan audit delay tidak berpengaruh secara bersama-sama terhadap kualitas audit pada perusahaan Property, real estate dan konstruksi yang tercatat di BEI tahun 2017-2019.

\section{KESIMPULAN DAN SARAN}

\section{Kesimpulan}

Tujuan penelitiannya untuk mengetahui pegaruhnya dari fee audit, rotasi audit, reputasi KAP dan audit delay terhadap perusahaan property, real estate dan konstruksi yang listing di BEI tahun 2017-2019. Pengamatan dilakukan dengan 22 perusahaan dengan total sebanyak 66 sampel. Berdasar hasil analisis dan pembahasannya maka dapat diambil kesimpullan yakni: 1).Hasil pengujian hipotesis variabel Fee audit memperlihatkan koefisien ialah 0,087 dan taraf signifikan 0,045 di atas 0,05. Dikarenakan taraf signifikan lebih kecil maka Fee audit mempengaruhi positif terhadap kualitas audit. 2).Hasil uji hipotesis variabel rotasi auditor memperlihatkan koefisien ialah 0,179 dan taraf signifikan 0,739 di atas 0,05. Dikarenakan taraf signifikan lebih tinggi maka rotasi audit tidak mempengaruhi kualitas audit, 3).Hasil uji hipotesis veriabel reputasi KAP memperlihatkan koefisien -0,348 dan taraf signifikansi 0,530 di atas 0,05. Dikarenakan taraf signifikan lebih tinggi maka reputasi KAP tidak mempengaruhi kualitas audit. 4).Hasil uji hipotesis variabel audit delay memperlihatkan koefisien ialah $-0,009$ dan taraf signifikan 0.489 di atas 0,05. Dikarenakan taraf signifikan lebih tinggi maka audit delay tidak mempengaruhi kualitas audit. 5).Hasil pengujian analisis regresi logistik memperlihatkan yakni Fee 
audit, rotasi audit, reputasi KAP dan audit delay tidak mempengaruhi secara serentak terhadap kualitas audit.

\section{Saran}

Adapun keterbatasan penelitiannya ialah ukuran sampel yang peneliti gunakan terbatas pada tiga tahun terakhir (2017-2019), oleh sebab itu diharapkam untuk peneliti selanjutnya supaya menambah tahun pengamatannya.

Peneliti selanjutnya dapat memperluas sampel pengamatan dengan tidak hanya melakukan pengamatan pada perusahaan Property, real estate dan konstruksi saja melainkan perusahaan industri lainnya. Penelitian berikutnya bisa memakai proksi lainnya untuk menilai kualitas audit misalnya akrual diskrisioner, dll.

\section{DAFTAR PUSTAKA}

Amirul Hadi Khasani, A. C. (2018). Tenure audit, reputasi auditor dan kualitas audit pada perusahaan manufaktur: analisis kompleksitas operasi sebagai pemoderasi. Jurnal Riset Akuntansi dan Perpajakan JRAP 15(1), 1-13.

Ardani, S. V. (2017). Pengaruh tenure audit, rotasi audit, audit fee terhadap kualitas audit dengan komite audit sebagai variabel moderasi (studi pada perusahaan keuangan yang terdaftar di BEI Tahun 2010-2014). Jurnal Akuntansi. 6(1), 1-12.

Evi Herianti, A. S. (2016). Pengaruh kualitas auditor, audit delay dan audit tenure terhadap kualitas audit perbankan yang terdaftar di BEI periode 2012-2014. Prosiding Seminar Nasional INDOCOMPAC Univeritas Bakrie: Jakarta

Fauziyah Althaf Amani, I. W. (2016). Pengaruh ukuran perusahaan, profitabilitas, opini audit dan umur perusahaan terhadap audit delay (studi empiris pada perusahaan property dan real estate yang terdaftar di Bursa Efek Indonesia pada Tahun 20122014). Jurnal Nominal V(1),135-150

Ghozali, I. (2016). Aplikasi analisis multivarieta dengan program IBM SPSS 23 Cetakan 8. Badan Penerbit Universitas Diponegoro: Semarang

I Gusti Ngurah Indra Pramaswaradana, I. B. (2017). Pengaruh audit tenure, audit fee, rotasi auditor, spesialisasi auditor dan umur publikasi pada kualitas audit. EJurnal Akuntansi Universitas Udayana 19(1), 168-194.

Indah Yunita Permatasari, C. D. (2018). Pengaruh fee audit, rotasi auditor, dan reputasi KAP terhadap kualitas audit. Jurnal Akuntansi Trisakti, 5(1), 81-94.

Irsyad Fauzan Prasetia, R. D. (2016). Pengaruh Tenur audit, rotasi audit dan reputasi KAP terhadap kualitas audit (studi pada perusahaan manufaktur yang terdaftar di Bursa Efek Indonesia Tahun 2011-2014). Jurnal Aset (Akuntansi Riset) 8(1), 4960.

Kurniasih, M. A. (2014). Pengaruh fee audit, audit tenure dan rotasi audit terhadap kualitas audit. Diponegoro Journal of Accounting, 3(3).549-558

Malem Ukur Tarigan, P. B. (2013). Pengaruh kompetensi, etika, dan fee audit terhadap kualitas audit. Jurnal Akuntansi, 13(1), 803-832.

Muhammad Iqbal, I. J. (2015). Pengaruh masa penugasan audit dan spesialisasi kap terhadap kualitas audit-suatu studi dengan pendekatan earnings suprise benchmark. Diponegoro Journal of Accounting, 4(4).250-267

Ninik Andriani, N. (2018). Pengaruh fee audit, audit tenure, rotasi audit dan reputasi auditor terhadap kualitas audit. Riset Akuntansi dan Keuangan Indonesia, 3(1), 29-39

Nizar, A. A. (2017). Pengaruh rotasi, reputasi dan spesialisasi auditor terhadap kualitas audit (studi empiris pada perusahaan manufaktur listed di BEI). Jurnal Ilmiah 
Akuntansi:Kompartemen, XV(2).150-161

Simbolon, L. (2018). Pengaruh ukuran perusahaan, reputasi KAP, audit tenure, dan rotasi audit terhadap kualitas audit pada perusahaan manufaktur yang terdaftar di Bursa Efek Indonesia. Skripsi, Universitas Sumatera Utara: Medan

Tri Agustini, D. L. (2020). Pengaruh fee audit, audit tenure dan rotasi audit terhadap kualitas audit di Bursa Efek Indonesia. Jurnal EMBA, 8(1), 637-646

Wiranti, A. I. (2018). Pengaruh spesialisasi auditor, rotasi audit, dan ukuran kap terhadap kualitas audit pada perusahaan perbankan yang terdaftar di Bursa Efek Indonesia. Skripsi. Universitas Sumatera Utara: Medan 